\title{
Assistência editorial através do PROATEC na FFP-UERJ: um estudo de caso sobre suporte e impactos
}

Maria Betânia Almeida Pereira (FFP-UERJ) e Mariane Ferrari Macabu (FFP-UERJ)

O presente trabalho é fruto de a pesquisa-ação cooptativa feita através de um minicurso intitulado Introdução à assistência editorial de periódicos eletrônicos, usando um questionário no ato da inscrição e outro ao fim do minicurso, com a autorização da divulgação das respostas, mediante assinatura de Termo de Consentimento Livre e Esclarecido de todos os envolvidos na pesquisa, como "medida preventiva [...] para assegurar que os atingidos não estejam sendo enganados, manipulados ou explorados", como sugere David Tripp (2005, p. 455). Entende-se que se trata de uma pesquisa-ação porque se encaixa nas definições de Tripp (2005, p. 447), uma vez que "é uma forma de investigação-ação que utiliza técnicas de pesquisa consagradas para informar a ação que se decide tomar para melhorar a prática". Pode-se considerar uma pesquisa-ação com "cooptação" (TRIPP, 2005, p. 454) porque a pesquisadora conseguiu persuadir alguns dos inscritos no minicurso a participarem da presente pesquisa a partir do termo de consentimento livre e esclarecido mencionado anteriormente, alinhando-se com Tripp quando ele afirma que "a pesquisa-ação tende a ser participativa" (2005, p. 454).

\section{Interesse dos inscritos no minicurso}

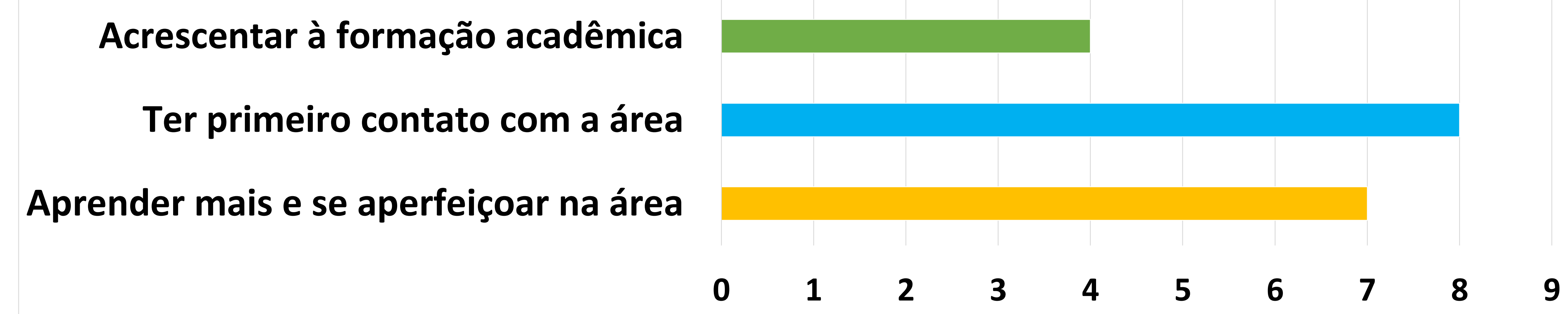

Fonte: a pesquisadora. Resultado obtido a partir das respostas dos 19 inscritos que autorizaram o uso de sua resposta para a presente pesquisa, através de assinatura do Termo de Consentimento Livre e Esclarecido.

Segurança dos participantes para trabalharem na área de editoração de periódicos eletrônicos após o minicurso

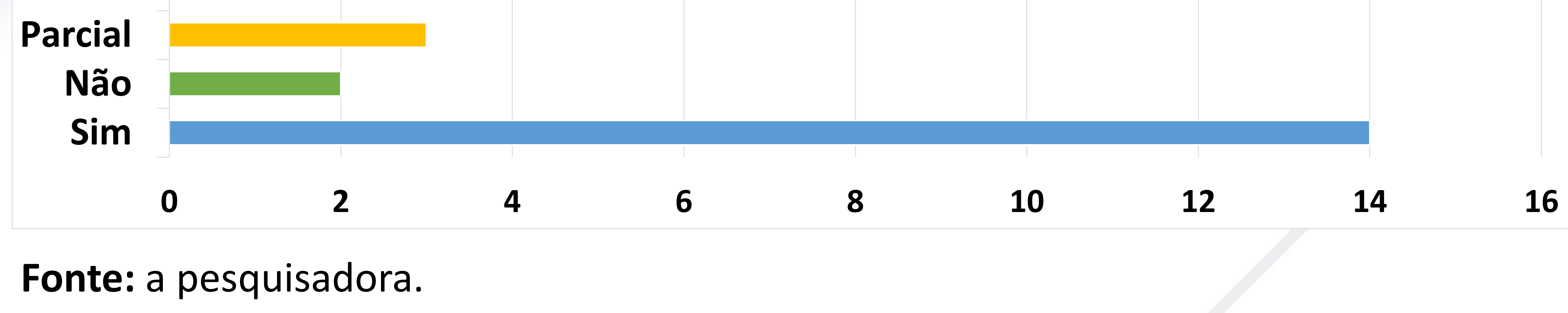

Esses resultados foram vistos como satisfatórios, pois a pesquisadora e a coordenadora entendem, através de uma análise geral, que esse minicurso ajudou, principalmente, uma parcela dos estudantes da FFP-UERJ, introduzindo-os ou aperfeiçoando-os na área de editoração de periódicos eletrônicos, e, assim, despertando seus interesses nessa possibilidade de carreira. Para muitos, foi o primeiro contato/curso que fizeram com esse assunto, o que demonstra a importância dessa iniciativa, pois não sairão da graduação sem terem ao menos conhecido um pouco esse tipo de trabalho.

Este é um projeto ainda em andamento. A pesquisadora e a coordenadora do projeto pretendem usar os resultados dos questionários para planejar outros cursos e oficinas, e até eventos voltados para a assistência editorial dentro da instituição de origem, atraindo cada vez mais pessoas interessadas. Percebe-se que tais atividades possibilitam o constante contato com a editoração de periódicos eletrônicos, o que faz com que os estudantes de graduação ampliem suas áreas de atuação. 